\title{
Expression of heparanase mRNA in bovine placenta during gestation
}

\author{
K. Kizaki, H. Nakano, H. Nakano, T. Takahashi, K. Imai \\ and K. Hashizume* \\ Laboratory of Reproductive Endocrinology, Department of Animal Reproduction, \\ National Institute of Animal Industry, Tsukuba-norindanchi, PO Box 5, Tsukuba, \\ Ibaraki 305-0901, Japan
}

This study reports the identification and sequence of a partial cDNA for bovine heparanase and the expression of its mRNA in the placenta during gestation. The 364 amino acid residues deduced from the 1092 bp cDNA fragment share $81.9 \%$ and $\mathbf{8 0 . 5} \%$ identity with amino acid sequences of human and rat heparanase, respectively. Northern blot hybridization showed that two mRNAs (2.0 and $3.5 \mathrm{~kb}$ ) are strongly expressed in placenta, and weakly expressed in the kidney, lung, spleen and non-pregnant uterus. In the placenta, these transcripts were detected in the cotyledon at all stages of gestation examined, and in the intercotyledonary fetal membrane and caruncle on day 60, day 120 and day 260. Quantitative real-time RT-PCR analysis showed very low expression of heparanase mRNA in the conceptus before implantation (day 17), but high expression in the cotyledon-containing fetal membrane (days 27-34) after implantation. Furthermore, heparanase mRNA was detected in the cotyledon, intercotyledonary fetal membrane and caruncle after days 60-64 of gestation. However, no significant expression of heparanase mRNA was observed in intercaruncular endometrium at all stages of gestation examined. These results demonstrate that heparanase mRNA is expressed in the placentome, indicating that heparanase may play a role in implantation, and in placental development and function.

\section{Introduction}

Heparan sulphate proteoglycans (HSPGs) play a role in various physiological processes such as cell adhesion, migration, differentiation and proliferation (Wight et al., 1992; Taipale and Keski-Oja, 1997). HSPGs reside at the surface of the plasma membrane as well as in the extracellular matrix (ECM) of various types of cell (Kjellen and Lindah, 1991). Heparan sulphate interacts with ECM components such as collagen, laminin and fibronectin, and many growth factors that are also found in the ECM, such as basic fibroblast growth factor, vascular endothelial growth factor and platelet-derived growth factor (Wight et al., 1992; Taipale and Keski-Oja, 1997). Heparanase is an endo- $\beta$-D-glucuronidase that degrades heparan sulphate side chains of HSPGs in the ECM (Nakajima et al., 1983, 1984). Several groups have reported detection of heparanase activity in various tumour cells, platelets and placenta (Nakajima et al., 1983, 1984; Vlodavsky et al., 1983; Goshen et al., 1996; Freeman and Parish, 1998). Expression of heparanase is correlated with the metastatic potential of tumour cells as well as that acquired by

*Correspondence

Email: kazuha@niai.affrc.go.jp cells transfected with human heparanase cDNA (Vlodavsky et al., 1999). These findings indicate that heparanasemediated degradation of heparan sulphate in the ECM may be critical during cell invasion associated with tumour metastasis and inflammation (Bartlett et al., 1995; Vlodavsky et al., 1999).

Remodelling of the ECM occurs during implantation and placental development in the uterus (Cross et al., 1994; Wooding and Flint, 1994). Studies show that the ECMdegrading proteinases, such as matrix metalloproteinase-9 and urokinase-type plasminogen activator, are potential major regulators during implantation and placental development (Librach et al., 1991; Behrendtsen et al., 1992; Zhang et al., 1996). Although there are no reports that heparanase plays a role in these events in any species, HSPG degradation may be essential in these processes since heparanase is strongly expressed in human placenta (Hulett et al., 1999; Kussie et al., 1999).

The cloning of human heparanase cDNA has been reported (Hulett et al., 1999; Kussie et al., 1999; Vlodavsky et al., 1999; Toyoshima and Nakajima, 1999), as has the tissue distribution of its mRNA expression (Hulett et al., 1999; Kussie et al., 1999). The aim of the present study, was to clone a cDNA encoding a portion of bovine heparanase and determine the expression of heperanase mRNA in bovine placenta during gestation. 


\section{Materials and Methods}

\section{Materials}

Reagents were purchased from Wako Pure Chemical Industries (Osaka), unless otherwise indicated. ISOGEN was purchased from Nippon gene (Toyama). Super Script ${ }^{\mathrm{TM}}$ II reverse transcriptase and first strand cDNA synthesis kit were obtained from Life Technologies, Inc. (Rockville, MD). DNA ligation kit, RACE kit and restriction enzymes were purchased from Takara Shuzo Co. (Kyoto). pBluescript $\mathrm{SK}(+)$ cloning vector was purchased from Stratagene (La Jolla, CA). AmpliTaq gold DNA polymerase, TaqMan gold RT-PCR kit and dye terminator sequencing kit were purchased from Perkin-Elmer Applied Biosystems (Foster City, CA). pGEM-T easy vector was purchased from Promega (Madison, WI). Digoxigenin (DIG) RNA labelling kit, anti-DIG alkaline phosphatase conjugate (Fab fragments) and positively charged nylon filters were obtained from Roche Molecular Biochemicals (Basel). CDP-star ${ }^{\circledR}$ was purchased from TROPIX (Bedford, MA). All culture regents were purchased from Sigma (St Louis, MO).

\section{Animals and tissues}

Placental and organ tissues were collected from Japanese Black and Holstein cows on days 27-34, days 60-64, days 100-148 and days 215-260 of gestation $(n=3-4$ per stage). Fetal and maternal portions of the placentome, intercotyledonary fetal membrane and intercaruncular endometrium were collected separately for RNA extraction. The cotyledon was separated mechanically from the uterine caruncle. Conceptus samples from day 17 of gestation were obtained from the uterus by flushing, and the conceptus was separated from the debris of the endometrium under a stereomicroscope (Nikon SMZ-10, Tokyo). All samples were frozen in liquid nitrogen and stored at $-80^{\circ} \mathrm{C}$ until RNA extraction.

\section{Reverse transcription and amplification of CDNA}

Total RNA was isolated from bovine placenta using ISOGEN according to the manufacturer's instructions for northern blot hybridization and RT-PCR. Total RNA ( $2 \mu \mathrm{g})$ was used for reverse transcription in a $20 \mu \mathrm{l}$ reaction volume. The total RNA was reverse transcribed with $200.0 \mathrm{U}$ Super Script ${ }^{\mathrm{TM}}$ II reverse transcriptase in the presence $0.5 \mu \mathrm{g}$ Oligo dT primer, $500.0 \mu \mathrm{mol}$ deoxynucleotide $\mathrm{I}^{-1}$ mixture,

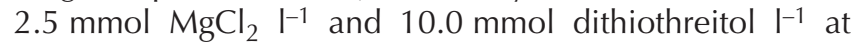
$42^{\circ} \mathrm{C}$ for $50 \mathrm{~min}$. After heat inactivation of reverse transcriptase at $70^{\circ} \mathrm{C}$ for $5 \mathrm{~min}, 2 \mathrm{U}$ ribonuclease $\mathrm{H}$ was added to the reaction mixture and incubated for $20 \mathrm{~min}$ at $37^{\circ} \mathrm{C}$ before PCR. On the basis of highly conserved regions of the human and rat protein sequence corresponding to the coding region of human heparanase from amino acid 283 to 497 (Hulett et al., 1999), two PCR primers were designed (5'-CTGAAGGCTGGTGGAGAAGTGAT-3' and $5^{\prime}$-CATTGAGTTGGACAGATTTGGA-3'). PCR reaction mixtures containing cDNA template, $0.5 \mu \mathrm{mol}$ primers $\mathrm{I}^{-1}$,
$0.2 \mathrm{mmol}$ deoxynucleotide $\mathrm{I}^{-1}$ mixture and $0.1 \mathrm{U}$ AmpliTaq gold DNA polymerase $\mu^{-1}$ were placed in a thermal cycler (MJ Research, Inc., Watertown, MA) under the following conditions (in order of denaturation, annealing and extension): $93^{\circ} \mathrm{C}$ for $30 \mathrm{~s}, 60^{\circ} \mathrm{C}$ for $30 \mathrm{~s}$ and $72^{\circ} \mathrm{C}$ for $1 \mathrm{~min}$. Amplified cDNA products were treated with T4 polynucleotide kinase, and then subcloned (using the DNA ligation kit) into pBluescript $\mathrm{SK}(+)$ that had been digested with EcoR $V$ and calf intestine alkaline phosphatase. DNA sequencing was performed with both T7 and T3 primers using the dye terminator sequencing kit. After determination of cDNA sequence, 5' - and 3'-rapid amplification of cDNA ends (RACE) was performed using the RACE kit according to the manufacturer's instructions. The resulting cDNA fragments were subcloned into PGEM-T easy vector and sequenced as described above.

RT-PCR was also performed using primers for bovine placental lactogen (Schuler et al., 1988) and $\beta$-actin (Degen et al., 1983) cDNAs, under the conditions described above. Two amplified cDNA products for placental lactogen were detected and lower molecular mass product represented an alternatively spliced variant (Kessler and Schuler et al., 1991). Amplified cDNA products for $\beta$-actin (892 bp) were subcloned into pBluescript $\mathrm{SK}(+)$ as described above.

\section{Hybridization probe}

DIG-labelled single strand cRNA probes were prepared using a DIG RNA labelling kit according to the manufacturer's instructions. Briefly, the cDNA fragment of bovine heparanase (643 bp) was subcloned into the Hind III-EcoR I sites of the pSPT 18 vector. The resultant plasmid was either linearized with Hind III followed by transcription with T7 RNA polymerase to generate the antisense probe, or linearized with EcoR I followed by transcription with SP6 RNA polymerase to generate the sense probe. DIG-labelled $\beta$-actin cRNA probe was prepared using the same method.

\section{Northern blot hybridization}

Northern blot hybridization was performed as described by Ishii et al. (1996). Total RNA $(10 \mu \mathrm{g})$ was fractionated on a $1.2 \%(\mathrm{w} / \mathrm{v})$ agarose-formaldehyde gel. RNA was transferred overnight by capillary action in $20 \times$ standard saline citrate $(20 \times$ SSC: $3.0 \mathrm{~mol} \mathrm{NaCl} \mathrm{I-1}, 0.3 \mathrm{~mol}$ sodium citrate ${ }^{-1}, \mathrm{pH} 7.4$ ) on to a positively charged nylon filter and immobilized by UV irradiation. The filter was prehybridized for $1 \mathrm{~h}$ in hybridization buffer consisting of $50 \%(\mathrm{v} / \mathrm{v})$ formamide, $5 \times \mathrm{SSC}, 2 \%(\mathrm{w} / \mathrm{v})$ blocking reagent (Roche Molecular Biochemicals), $0.1 \mathrm{mg}$ yeast tRNA $\mathrm{ml}^{-1}, 0.1 \%$ $(\mathrm{v} / \mathrm{v}) \quad \mathrm{N}$-lauroyl sarcosine and $0.1 \% \quad(\mathrm{w} / \mathrm{v})$ SDS. Hybridization was performed with a DIG-labelled cRNA probe in hybridization buffer at $68^{\circ} \mathrm{C}$ overnight. After hybridization, the filter was washed twice with $2 \times$ SSC containing $0.1 \%(\mathrm{w} / \mathrm{v})$ SDS for $15 \mathrm{~min}$ at room temperature, followed by two washes each of $30 \mathrm{~min}$ in $0.1 \times \mathrm{SSC}$ containing $0.1 \%(\mathrm{w} / \mathrm{v}) \mathrm{SDS}$ at $68^{\circ} \mathrm{C}$. The filter was then incubated for $1 \mathrm{~h}$ in $0.1 \mathrm{~mol}$ maleic acid $\mathrm{I}^{-1}$ and $0.15 \mathrm{~mol}$ 
$\mathrm{NaCl} \mathrm{I}^{-1}$ containing $1 \%(\mathrm{w} / \mathrm{v})$ blocking reagent (blocking buffer), and incubated further in anti-DIG alkaline phosphatase-conjugate antibody diluted 1:10000 in blocking buffer. After $1 \mathrm{~h}$, the filter was washed three times with $0.1 \mathrm{~mol}$ maleic acid $\mathrm{I}^{-1}$ and $0.15 \mathrm{~mol} \mathrm{NaCl} \mathrm{I^{-1 }}$ containing $0.3 \%(\mathrm{w} / \mathrm{v})$ Tween 20 for $15 \mathrm{~min}$ at room temperature followed by $5 \mathrm{~min}$ of rinsing in $0.1 \mathrm{~mol}$ Tris- $\mathrm{HCl} \mathrm{I}{ }^{-1}(\mathrm{pH} 9.5)$ containing $0.15 \mathrm{~mol} \mathrm{NaCl}{ }^{-1}$ and $50.0 \mathrm{mmol} \mathrm{MgCl}_{2} \mathrm{I}^{-1}$. For signal detection, the filter was incubated for $5 \mathrm{~min}$ in $0.25 \mathrm{mmol}$ CDP-star ${ }^{\circledR} \mathrm{I}^{-1}$ as a chemiluminescent substrate, and exposed to Kodak XAR-5 film for 1-20 min.

\section{Real-time $R T-P C R$ analysis}

This novel technique has been used to monitor mRNA expression quantitatively and was described in detail by Heid et al. (1996) and Gerber et al. (1997). Briefly, 50.0 ng total RNA was reverse transcribed with $12.5 \mathrm{U}^{\text {MultiScrbe }}{ }^{\mathrm{TM}}$ reverse transcriptase in the presence of $2.5 \mu \mathrm{mol}$ Oligo dT primer $\mathrm{I}^{-1}, 500.0 \mu \mathrm{mol}$ deoxynucleotide $\mathrm{I}^{-1}$ mixture, $5.5 \mathrm{mmol} \mathrm{MgCl}_{2} \mathrm{I}^{-1}$ and 20 iu RNase inhibitor at $48^{\circ} \mathrm{C}$ for $30 \mathrm{~min}$. After heat inactivation of reverse transcriptase at $95^{\circ} \mathrm{C}$ for $5 \mathrm{~min}, \mathrm{PCR}$ and the resulting relative increase in reporter fluorescent dye emission were monitored in realtime using the 7700 sequence detector (Perkin-Elmer Applied Biosystems). Primers and oligonucleotide probes labelled with a reporter fluorescent dye at the 5 '-end and a quencher fluorescent dye at the 3 '-end were designed by the Primer Express Program (Perkin-Elmer Applied Biosystems). The primers and probes were as follows: heparanase forward primer 5'-GACCCCTCAAGAAGGTTTGGT-3', reverse primer 5'-GCCGACAGGCCCAATTT-AT-3' and probe 5'-TGTCCAACACCTTTGCTGCTGGCTTTA-3'; glyceraldehyde-3-phosphate dehydrogenase (GAPDH) forward primer 5'-AAGGCCATCACCATCTT-CCA-3', reverse primer 5'-CCACTACATACTCAGCACCAGCAT-3' and probe 5'-AGCGAGATCCTGCCAACATCAAGTGG-3'. The thermal cycling conditions included one cycle at $50^{\circ} \mathrm{C}$ for $2 \mathrm{~min}$, one cycle at $95^{\circ} \mathrm{C}$ for $10 \mathrm{~min}$ and 45 cycles at $95^{\circ} \mathrm{C}$ for $15 \mathrm{~s}$ and at $60^{\circ} \mathrm{C}$ for $1 \mathrm{~min}$. The standard curves for each gene were generated by serial dilution of the total RNA isolated from cotyledon at day 60 of gestation.

\section{Cell preparation}

Briefly, bovine fetal cotyledon at day 240 of gestation was minced and digested with collagenase, and the resultant cell suspension was fractionated using Percoll discontinuous density gradient $\left(1.03-1.08 \mathrm{~g} \mathrm{ml}^{-1}\right)$ centrifugation at $800 \mathrm{~g}$ for $20 \mathrm{~min}$ at room temperature. Binucleate cells sedimenting at the density range $1.05-1.06 \mathrm{~g} \mathrm{ml}^{-1}$ were separated and cultured with Dulbecco's modified Eagle's medium-F12 medium (DMEM-F12) containing 100 iu penicillin $\mathrm{ml}^{-1}$ and $100 \mu \mathrm{g}$ streptomycin $\mathrm{ml}^{-1}$ supplemented with $5 \%(\mathrm{v} / \mathrm{v})$ fetal bovine serum (FBS) in a humidified atmosphere of $5 \% \mathrm{CO}_{2}$ at $37^{\circ} \mathrm{C}$. On the subsequent day, non-adherent cells were removed by washing, and total RNA was extracted from the binucleate cell-rich fraction that remained adhered to the culture apparatus. On the basis of morphology, the adherent fraction consisted of approximately $50 \%$ binucleate cells and the remaining $50 \%$ consisted primarily of uninucleate cells and fibroblasts. Cotyledon-derived fibroblasts sedimenting at the density range $1.03-1.04 \mathrm{~g} \mathrm{~m}^{-1}$ were separated and cultured with DMEM-F12 supplemented with 5\% (v/v) FBS. The cells consisted of $>90 \%$ fibroblasts, as assessed by morphology, and showed vimentin-positive and cytokeratinnegative staining. After the tenth passage in culture, total RNA was extracted from the cells.

\section{Statistical analysis}

Statistical analysis was performed using one-way ANOVA followed by Tukey's multiple comparisons test. Differences were considered significant at $P<0.05$.

\section{Results}

\section{Partial cloning of heparanase cDNA from the bovine placenta}

The cDNA fragment of bovine heparanase, corresponding to the C-terminal coding region of human and rat heparanase (Hulett et al., 1999), was amplified using a first strand cDNA from fetal cotyledonary tissue of bovine placenta at day 60 of gestation. A 643 bp cDNA fragment was obtained using a PCR approach with primers based on the human heparanase sequence, showing high homology (> 80\%) with human and rat heparanase cDNA. On the basis of the 643 bp cDNA sequence, amplification of 5'- and 3'-ends of bovine heparanase cDNA was performed. The partial cDNA consisted of 1125 bp obtained by the RACE procedure, which included an open reading frame of 1092 bp (encoding 364 amino acid residues) followed by a 3' untranslated region. Alignment of the deduced amino acid sequence of human, rat and bovine heparanase indicated $81.9 \%$ and $80.5 \%$ identity between human and bovine, and rat and bovine heparanase, respectively (Fig. 1). Conserved potential $\mathrm{N}$ linked glycosylation sites, located at amino acid residues 38 and 280 in bovine heparanase, are also found in human and rat heparanase (Hulett et al., 1999; Kussie et al., 1999; Vlodavsky et al., 1999).

\section{Tissue distribution of bovine heparanase $m R N A$}

Northern blot analysis was performed to investigate the distribution of heparanase mRNA in bovine tissues (Fig. 2). DIG-labelled bovine heparanase cRNA detected two mRNA transcripts (2.0 and $3.5 \mathrm{~kb}$ ) in cotyledonary tissue of the fetal placenta. The intensities of the two mRNA bands indicate that they are present in similar amounts in placental tissue. The $3.5 \mathrm{~kb}$ transcript was also detected weakly in the kidney, lung, spleen and non-pregnant uterus. No hybridization was detected in other bovine tissues, including brain, heart and liver, and no signal was obtained when a sense probe was used during hybridization (data not shown). 


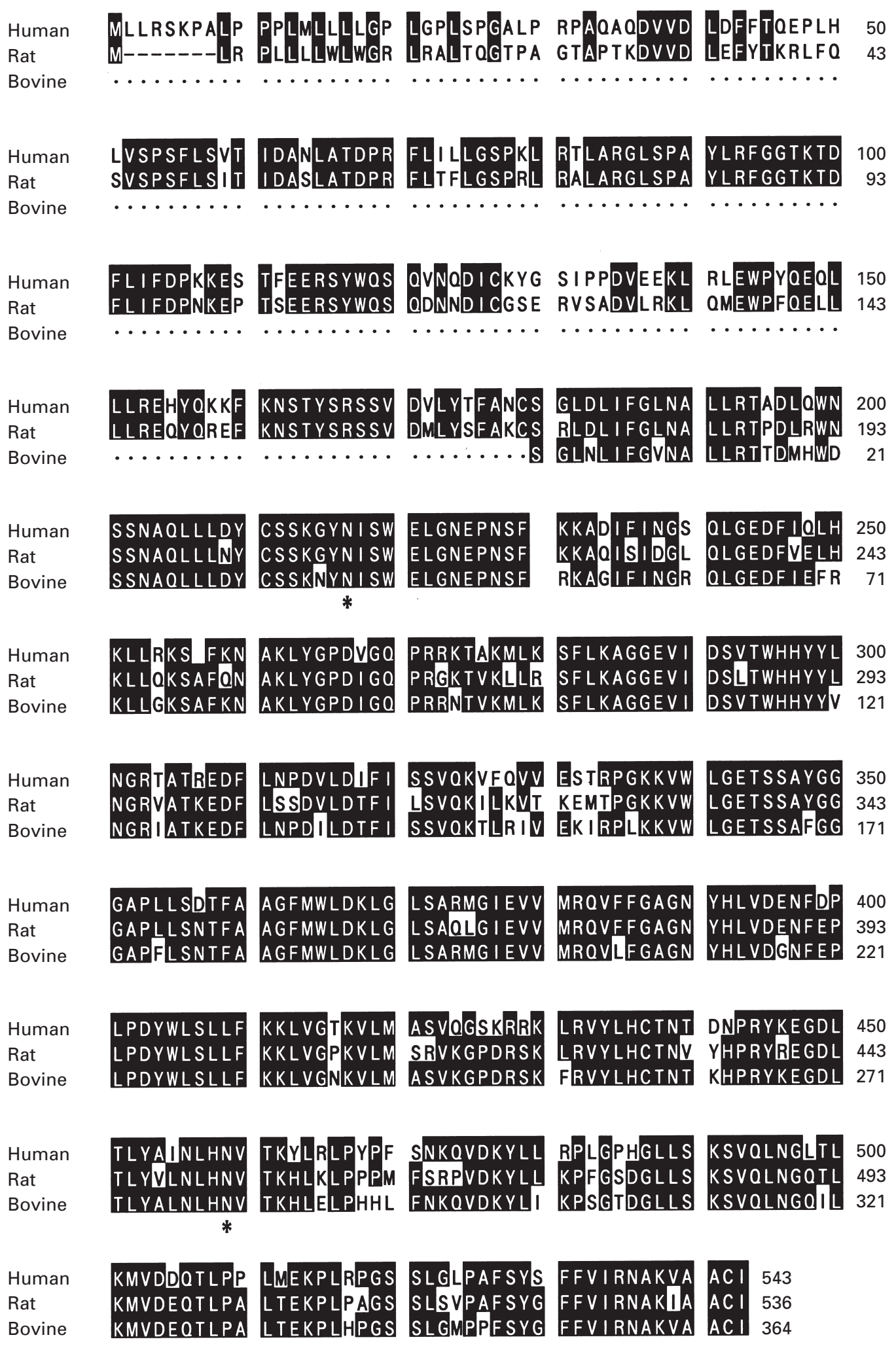

Fig. 1. Amino acid alignment of human, rat and bovine heparanase. The amino acid sequences of human and rat heparanase were deduced from their full-length cDNAs (human, GenBank accession no. AF165154; rat: GenBank accession no. AF184967). The bovine sequence was deduced from a partial cDNA and lacks the N-terminal region. The nucleotide sequence of bovine heparanase was submitted to the GenBank Database under accession no. AF281160. Shaded residues indicate conserved residues in at least two species. The putative $\mathrm{N}$-linked glycosylation sites of bovine heparanase are indicated by asterisks (amino acids 38 and 280). 


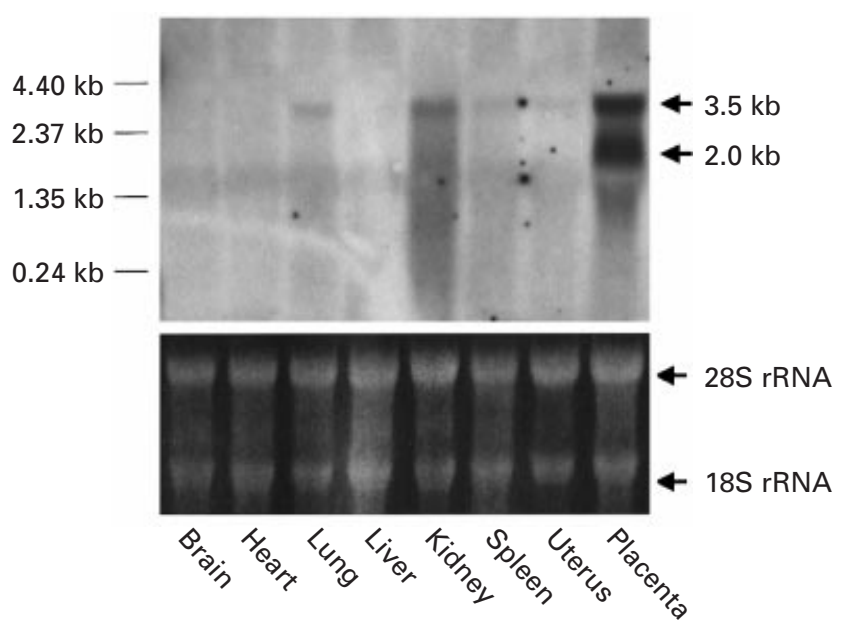

Fig. 2. Expression of heparanase mRNA in bovine tissues. Upper panel: each lane contains $10 \mu \mathrm{g}$ total RNA extracted from bovine brain, heart, lung, liver, kidney, spleen, non-pregnant uterus or placenta. Cotyledonary tissue at day 60 of gestation was used as a placental sample. Heparanase mRNA content was analysed by northern blot analysis. RNA molecular markers are indicated on the left-hand side margin. Lower panel: ethidium bromide-stained $28 \mathrm{~S}$ and $18 \mathrm{~S}$ ribosomal RNA (28S and $18 \mathrm{~S}$ rRNA), demonstrating the uniformity of loading and the RNA integrity of each sample.

\section{Gestational profile of heparanase mRNA in bovine placenta}

Northern blot hybridization showed that the expression of heparanase mRNA in the conceptus from day 17 of gestation was below the limit of detection (Fig. 3). The expression of mRNA was evident in the cotyledoncontaining fetal membrane at day 30, and cotyledon, intercotyledonary fetal membrane and caruncle at days 30-260. However, the expression of heparanase mRNA was not detected in the intercaruncular endometrium on days 30-120, although the $3.5 \mathrm{~kb}$ transcript was weakly expressed on day 260.

Furthermore, quantitative real-time RT-PCR analysis showed very low expression of heparanase mRNA in the conceptus at day $17(0.027 \pm 0.025$ heparanase/GAPDH mRNA). However, significantly higher expression of heparanase mRNA was detected in fetal membranes than in the caruncle and intercaruncle endometrium on days 27-34 of gestation $(P<0.05)$ (Fig. 4a). However, on days 60-64, the expression of heparanase mRNA in the cotyledon was higher than that in the intercaruncle endometrium $(P<0.05)$ (Fig. 4b). No significant differences were observed in all placental tissues on days 100-148 (Fig. 4c). On days 215-260, higher expression of heparanase mRNA was detected in the cotyledon and caruncle (Fig. 4d). The heparanase mRNA content in the cotyledon did not change throughout gestation from days 27-34 to days 215-260, but a significant increase was detected in the caruncle as gestation progressed $(P<0.05)$. Throughout gestation, intercaruncular expression of heparanase mRNA was lower than that in the caruncle.

\section{Expression of heparanase mRNA in binucleate cell-rich fraction}

Placental cell fractions were examined by RT-PCR to clarify the source of heparanase. Heparanase mRNA was found in the binucleate cell-rich fraction from cotyledon at day 240 of gestation, but not in cotyledon-derived fibroblasts (Fig. 5). Similarly, expression of placental lactogen mRNA, produced only by binucleate cells (Anthony et al., 1992), was also detected in the cotyledon and the binucleate cellrich fraction, but not in cotyledon-derived fibroblasts.

\section{Discussion}

This study reports the cloning of a partial cDNA of bovine heparanase encoding the C-terminal region of human and rat heparanase (Hulett et al., 1999; Kussie et al., 1999;

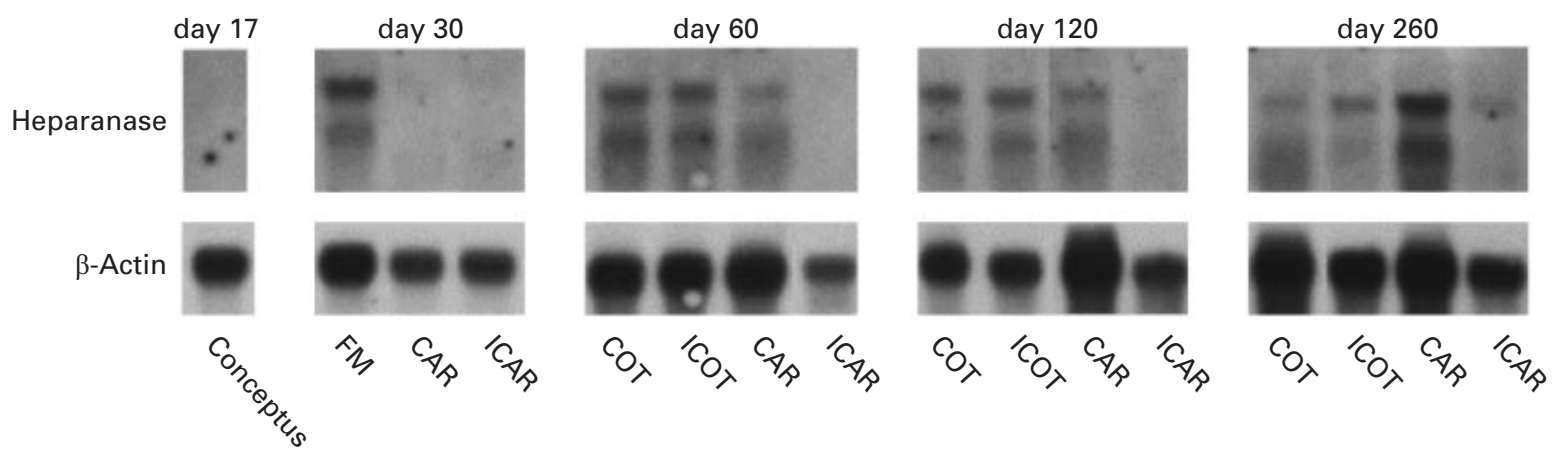

Fig. 3. Expression of heparanase mRNA in bovine placenta using northern blotting analysis. Total RNA (10 $\mu \mathrm{g})$ was extracted from tissues at various times (days) during gestation as indicated. Placental samples were labelled as follows: cotyledon containing fetal membrane (FM), cotyledon (COT), intercotyledonary fetal membrane (ICOT), caruncle (CAR), intercaruncular endometrium (ICAR). A DIG-labelled $\beta$-actin cRNA probe that was hybridized to the same filter is shown in the lower panel. 
(a)

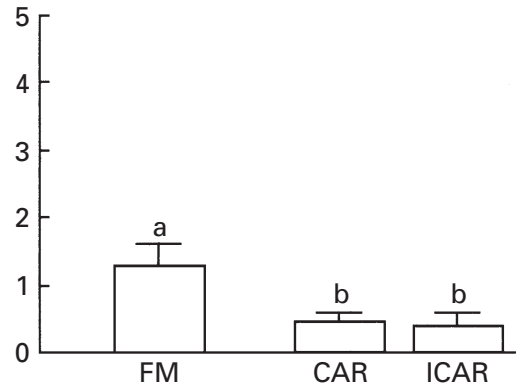

(b)

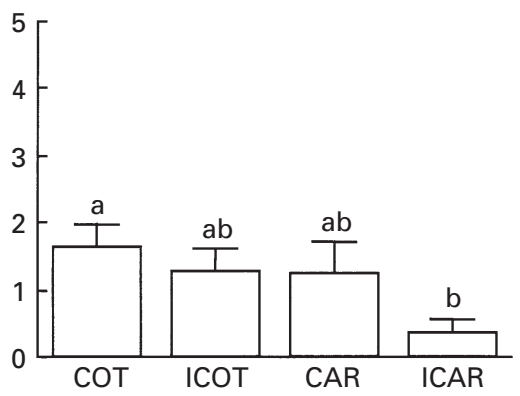

(c)

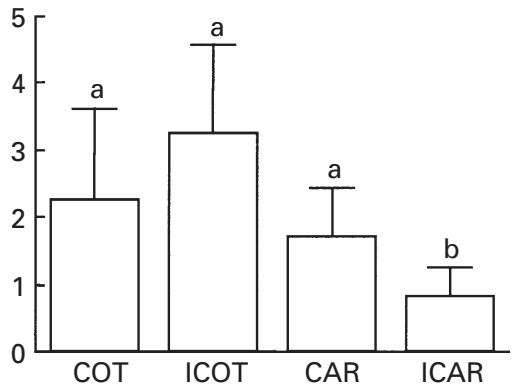

(d)

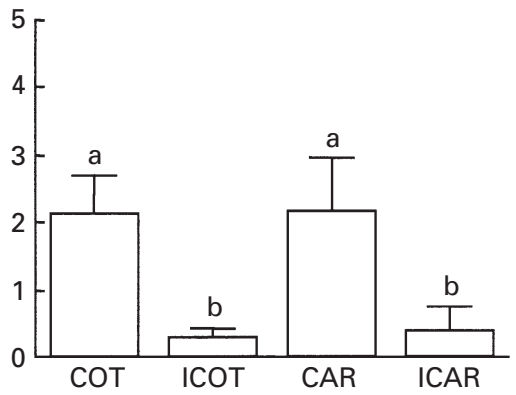

Fig. 4. Quantitative real-time RT-PCR analysis of heparanase mRNA in bovine placenta. Total RNA (50 ng) was extracted from cotyledon containing fetal membrane (FM), cotyledon (COT), intercotyledonary fetal membrane (ICOT), caruncle (CAR) and intercaruncular endometrium (ICAR) on days 27-34 (a), days 60-64 (b), days 100-148 (c) and days 215-260 (d) of gestation. Heparanase mRNA content was analysed by real-time RT-PCR. The expression of heparanase mRNA was normalized to the expression of GAPDH measured in the same RNA preparation. Values are means $\pm \operatorname{SEM}(n=3-4)$. Values with different letters are significantly different $(P<0.05)$.

Toyoshima and Nakajima, 1999; Vlodavsky et al., 1999). The deduced amino acid sequence of bovine heparanase shows $81.9 \%$ and $80.5 \%$ identity with human and rat

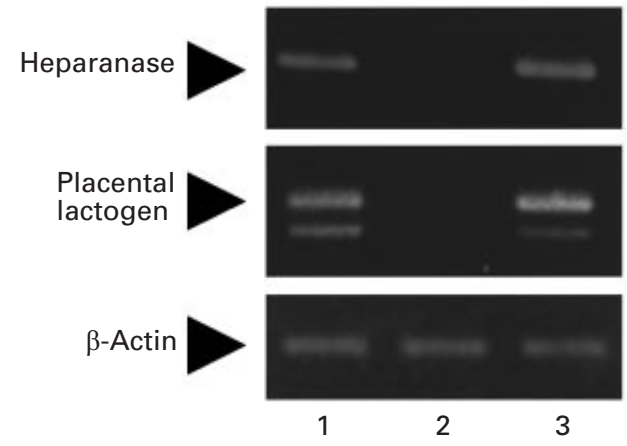

Fig. 5. Expression of heparanase mRNA in the binucleate cell-rich fraction of bovine placenta at day 240 of gestation, as analysed by RT-PCR. Lane 1: whole cotyledon; lane 2: cotyledon-derived fibroblasts; and lane 3: binucleate cell-rich fraction.

heparanase, respectively, indicating that the amino acid residue is highly conserved.

Northern blot analysis of bovine tissues showed that two mRNA transcripts (2.0 and $3.5 \mathrm{~kb}$ ) were highly expressed in the placenta, as also reported in human tissue (Hulett et al., 1999; Kussie et al., 1999). In humans, heparanase mRNA of the expected size $(2.0 \mathrm{~kb})$ was detected only in the placenta among the non-immune tissues tested, but both $4.4 \mathrm{~kb}$ and $2.0 \mathrm{~kb}$ mRNAs were found in many immune tissues (Hulett et al., 1999). The present study demonstrates that heparanase mRNA is also strongly expressed in bovine placenta, and also indicates that the placenta is the major source of heparanase in bovine species. Recent reports indicate that heparanase plays an immunological role in physiological and pathological states, since human immune tissues as well as tumour tissues express heparanase (Hulett et al., 1999; Vlodavsky et al., 1999). In the present study, bovine immune tissues showed low expression of heparanase, and, therefore, its role remains to be elucidated.

The ruminant placenta is classified as synepitheliochorial (Cross et al., 1994; Wooding and Flint, 1994) and has a cotyledonary organization in which both fetal and maternal villi are discernible as discrete structures (placentome) on the uterine epithelium. In cows, implantation and the formation of the cotyledon begin at about day 20 of gestation (Wooding and Flint, 1994). Intimate contact between maternal and fetal tissues occurs only in the placentome (comprising the fetal cotyledon and maternal caruncle), which is the most highly vascularized portion of the placenta (Wooding and Flint, 1994). In the present study, the expression of heparanase mRNA in the placenta during gestation was examined using northern blot analysis and quantitative real-time RT-PCR. The results showed that heparanase mRNA is expressed in the placentome, which takes the central role of placental function, especially during implantation (Wooding and Flint, 1994).

Although the expression of heparan sulphate-binding angiogenic growth factors in bovine placenta has not been 
determined, the expression of basic fibroblast growth factor and vascular endothelial growth factor has been identified in placenta from many species (Gospodarowicz et al., 1985; Hondermarck et al., 1990; Sharkey et al., 1993; Zheng et al., 1997; Clark et al., 1998; Winther et al., 1999). Heparanase may mediate the liberation or activation of heparan sulphate-binding angiogenic growth factors from the ECM, and the growth factors may act as paracrine factors during angiogenesis at the fetal-maternal interface. In addition, degradation of the ECM of both fetal and maternal cells is required during the remodelling of placental tissues after attachment (Smith et al., 2000). The present study shows that the expression of heparanase mRNA accords with the timing of cotyledon formation in bovine placenta. As heparanase contributes to cell invasion and angiogenesis through degradation of heparan sulphate in the ECM during metastasis (Nakajima et al., 1983; Vlodavsky et al., 1983, 1999), the present study indicates that heparanase plays a critical role in the migration of trophoblasts during implantation and placental formation.

Although most bovine trophoblast cells are non-invasive, binucleate trophoblast cells may have invasive properties that promote fusion with the uterine epithelium on the caruncle (Cross et al., 1994). The possibility that the binucleate cells express heparanase was examined by collecting the binucleate cell-rich fraction from the cotyledon on day 240 of gestation, and performing RT-PCR for heparanase mRNA. Heparanase mRNA was observed in the binucleate cell-rich fraction as well as in the cotyledon. Immunohistochemistry revealed that heparanase is expressed in invasive extravillus trophoblast cells of human placenta (Dempsey et al., 2000). Invasive trophoblast cells, in a manner similar to that of human extravillus trophoblast cells, bovine binucleate cells and rodent giant cells, may use active enzymes such as heparanase and metalloproteinases for ECM remodelling. However, the possibility that other cells in the bovine placenta produce heparanase cannot be excluded, as the present study does not address directly the localization of heparanase in specific cells. Further studies on cellular localization are necessary to understand trophoblast invasiveness in relation to the function of placental heparanase.

In conclusion, the partial cDNA sequence of bovine heparanase was determined and it was established that the mRNA is expressed specifically in the placentome throughout gestation. This ECM-degrading enzyme may have an important role in cytokine activation during angiogenesis and placentation in cows.

This work was supported by the Organized Research Combination System from the Science and Technology Agency, by the Co-operative System for Supporting Priority Research from the Japan Science and Technology Corporation, and by the Biooriented Technology Research Advancement Institution, Japan. K. Kizaki and H. Nakano are supported by a fellowship from the Japan Science and Technology Corporation.

\section{References}

Anthony RV, Liang R, Kayl EP and Pratt SL (1992) The growth hormone/prolactin gene family in ruminant placentae Journal of Reproduction and Fertility Supplement 49 83-95

Bartlett MR, Underwood PA and Parish CR (1995) Comparative analysis of the ability of leucocytes, endothelial cells and platelets to degrade the subendothelial basement membrane: evidence for cytokine dependence and detection of a novel sulfatase Immunology and Cell Biology $\mathbf{7 3}$ 113-124

Behrendtsen O, Alexander CM and Werb Z (1992) Metalloproteinases mediate extracellular matrix degradation by cells from mouse blastocyst outgrowths Development 114 447-456

Clark DE, Smith SK, Licence D, Evans AL and Charnock-Jones DS (1998) Comparison of expression patterns for placenta growth factor, vascular endothelial growth factor (VEGF), VEGF-B and VEGF-C in the human placenta throughout gestation Journal of Endocrinology 159 459-467

Cross JC, Werb Z and Fisher SJ (1994) Implantation and the placenta: key pieces of the development puzzle Science 266 1508-1518

Degen JL, Neubauer MG, Degen SJ, Seyfried CE and Morris DR (1983) Regulation of protein synthesis in mitogen-activated bovine lymphocytes. Analysis of actin-specific and total mRNA accumulation and utilization Journal of Biological Chemistry 25812 153-12 162

Dempsey LA, Plummer TB, Coombes SL and Platt JL (2000) Heparanase expression in invasive trophoblasts and acute vascular damage Glycobiology 10 467-475

Freeman C and Parish CR (1998) Human platelet heparanase: purification, characterization and catalytic activity Biochemical Journal $\mathbf{3 3 0}$ 1341-1350

Gerber HP, Condorelli F, Park J and Ferrara N (1997) Differential transcriptional regulation of the two vascular endothelial growth factor receptor genes. Flt-1, but not Flk-1/KDR, is up-regulated by hypoxia Journal of Biological Chemistry 27223 659-23 667

Goshen R, Hochberg AA, Korner G, Levy E, Ishai-Michaeli R, Elkin M, de Groot N and Vlodavsky I (1996) Purification and characterization of placental heparanase and its expression by cultured cytotrophoblasts Molecular Human Reproduction 2 679-684

Gospodarowicz D, Cheng J, Lui GM, Fujii DK, Baird A and Bohlen P (1985) Fibroblast growth factor in the human placenta Biochemical and Biophysical Research Communications 128 554-562

Heid CA, Stevens J, Livak KJ and Williams PM (1996) Real time quantitative PCR Genome Research 6 986-994

Hondermarck H, Courty J, Ledoux D, Blanckaert V, Barritault D and Boilly B (1990) Evidence of high and low affinity binding sites for basic fibroblast growth factor in mouse placenta Biochemical and Biophysical Research Communications 169 272-281

Hulett MD, Freeman C, Hamdorf BJ, Baker RT, Harris MJ and Parish CR (1999) Cloning of mammalian heparanase, an important enzyme in tumor invasion and metastasis Nature Medicine 5 803-809

Ishii H, Kizaki K, Horie S and Kazama M (1996) Oxidized low density lipoprotein reduces thrombomodulin transcription in cultured human endothelial cells through degradation of the lipoprotein in lysosomes Journal of Biological Chemistry 271 8458-8465

Kessler MA and Schuler LA (1991) Structure of the bovine placental lactogen gene and alternative splicing of transcripts DNA and Cell Biology 10 93-104

Kjellen L and Lindahl U (1991) Proteoglycans: structures and interactions Annual Review of Biochemistry $60443-475$

Kussie PH, Hulmes JD, Ludwig DL, Patel S, Navarro EC, Seddon AP, Giorgio NA and Bohlen P (1999) Cloning and functional expression of a human heparanase gene Biochemical and Biophysical Research Communications 261 183-187

Librach CL, Werb Z, Fitzgerald ML et al. (1991) 92-kD type IV collagenase mediates invasion of human cytotrophoblasts Journal of Cell Biology 113 437-449

Nakajima M, Irimura T, Di Ferrante D, Di Ferrante N and Nicolson GL (1983) Heparan sulfate degradation: relation to tumor invasive and metastatic properties of mouse B16 melanoma sublines Science 220 $611-613$ 
Nakajima M, Irimura T, Di Ferrante D and Nicolson GL (1984) Metastatic melanoma cell heparanase. Characterization of heparan sulfate degradation fragments produced by B16 melanoma endoglucuronidase Journal of Biological Chemistry 259 2283-2290

Schuler LA, Shimomura K, Kessler MA, Zieler CG and Bremel RD (1988) Bovine placental lactogen: molecular cloning and protein structure Biochemistry 27 8443-8448

Sharkey AM, Charnock-Jones DS, Boocock CA, Brown KD and Smith SK (1993) Expression of mRNA for vascular endothelial growth factor in human placenta Journal of Reproduction and Fertility 99 609-615

Smith SK, He Y, Clark DE and Charnock-Jones DS (2000) Angiogenic growth factor expression in placenta Seminars in Perinatology 24 82-86

Taipale J and Keski-Oja J (1997) Growth factors in the extracellular matrix FASEB Journal 11 51-59

Toyoshima $\mathbf{M}$ and Nakajima M (1999) Human heparanase. Purification, characterization, cloning and expression Journal of Biological Chemistry 27424 153-24 160

Vlodavsky I, Fuks Z, Bar-Ner M, Ariav Y and Schirrmacher V (1983) Lymphoma cell-mediated degradation of sulfated proteoglycans in the subendothelial extracellular matrix: relationship to tumor cell metastasis Cancer Research 43 2704-2711

Vlodavsky I, Friedmann Y, Elkin M et al. (1999) Mammalian heparanase: gene cloning, expression and function in tumor progression and metastasis Nature Medicine 5 793-802
Wight TN, Kinsella MG and Qwarnstrom EE (1992) The role of proteoglycans in cell adhesion, migration and proliferation Current Opinion in Cell Biology 4 793-801

Winther H, Ahmed A and Dantzer V (1999) Immunohistochemica localization of vascular endothelial growth factor (VEGF) and its two specific receptors, Flt- 1 and KDR, in the porcine placenta and nonpregnant uterus Placenta $2035-43$

Wooding FBP and Flint APF (1994) Placentation. In Marshall's Physiology of Reproduction 3 pp 233-460 Ed. GE Lamming. Chapman \& Hall, London

Zhang X, Shu MA, Harvey MB and Schultz GA (1996) Regulation of urokinase plasminogen activator production in implanting mouse embryo: effect of embryo interaction with extracellular matrix Biology of Reproduction 54 1052-1058

Zheng J, Vagnoni KE, Bird IM and Magness RR (1997) Expression of basic fibroblast growth factor, endothelial mitogenic activity, and angiotensin II type-1 receptors in the ovine placenta during the third trimester of pregnancy Biology of Reproduction 56 1189-1197

Received 11 September 2000.

First decision 16 October 2000.

Accepted 14 November 2000. 